\title{
Differential response at the seafloor during Palaeocene and Eocene ocean warming events at Walvis Ridge, Atlantic Ocean (ODP Site 1262)
}

\author{
Arne Deprez, ${ }^{1}$ (D) Sofie Jehle, ${ }^{2}$ André Bornemann ${ }^{2,3}$ and Robert P. Speijer ${ }^{1}$ \\ ${ }^{1}$ Department of Earth and Environmental Sciences, KU Leuven, Heverlee 3001, Belgium; ${ }^{2}$ Institut für Geophysik und Geologie, Universität \\ Leipzig, Leipzig 04103, Germany; ${ }^{3}$ Bundesanstalt für Geowissenschaften und Rohstoffe, Hannover 30655, Germany
}

\begin{abstract}
The Latest Danian Event (LDE, c. 62.1 Ma) is an early Palaeogene hyperthermal or transient $(<200 \mathrm{ka})$ ocean warming event. We present the first deep-sea benthic foraminiferal faunal record to study deep-sea biotic changes together with new benthic (Nuttallides truempyi) stable isotope data from Walvis Ridge Site 1262 (Atlantic Ocean) to evaluate whether the LDE was controlled by similar processes as the minor early Eocene hyperthermals. The spacing of the double negative $\delta^{13} \mathrm{C}$ and $\delta^{18} \mathrm{O}$ excursion and the slope of the $\delta^{18} \mathrm{O}-\delta^{13} \mathrm{C}$ regression are comparable, strongly suggesting a similar orbital control and pacing of eccentricity maxima as well as a
\end{abstract}

rather homogeneous carbon pool. However, in contrast to early Eocene hyperthermals, the LDE exhibits a remarkable stability of the benthic foraminiferal fauna. This lack of benthic response could be related to the absence of threshold-related circulation changes or better pre-adaptation to elevated deep-sea temperatures, as the LDE was superimposed on a cooling trend, in contrast to early Eocene warming.

Terra Nova, 29: 71-76, 2017

\section{Introduction}

The early Palaeogene is characterized by numerous hyperthermals, transient $(<200 \mathrm{ka})$ deep-sea and surface-ocean warming events, associated with carbon isotope excursions (CIEs) and carbonate dissolution in the deep sea. Of these, the Palaeocene-Eocene Thermal Maximum (PETM; c. $56 \mathrm{Ma}$ ) is the most extreme example. The Latest Danian Event (LDE; Bornemann et al., 2009; c. $62.1 \mathrm{Ma}), \quad$ also referred to as the Top Chron $27 \mathrm{n}$ Event (Westerhold et al., 2011), is a minor hyperthermal compared to the PETM. Benthic and planktic foraminiferal isotope records indicate a $\sim 2-3{ }^{\circ} \mathrm{C}$ warming (Westerhold et al., 2011; Jehle et al., 2015) and a $\sim 0.7 \%$ negative CIE (Bornemann et al., 2009; Westerhold et al., 2011). Also peak values in XRF core scanning $\mathrm{Fe}$ records (Westerhold et al., 2008), anoxia in marginal basins (Sprong et al., 2012; Schulte et al., 2013) and biotic changes among calcareous nannofossils (Monechi et al., 2013), planktic foraminifera

Correspondence: Arne Deprez, Department of Earth and Environmental Sciences, KU Leuven, Heverlee 3001, Belgium. Tel.: +32 163721 95; e-mail: arne.deprez@ kuleuven.be
(Jehle et al., 2015) and mammals (Clyde et al., 2008) coinciding with the LDE are strongly reminiscent of the PETM. At present, it is unclear whether the LDE was controlled by similar processes as the minor early Eocene hyperthermals. Also, the biotic changes in the deep sea have not been studied so far.

This paper provides the first indepth comparison between isotope records spanning the $\mathrm{LDE}$ and the Eocene ETM2-H2 hyperthermals, as recorded at Walvis Ridge ODP Site 1262 (Stap et al., 2010). We combine the isotopic data with benthic foraminiferal abundance patterns in order to evaluate relationships between transient warming events and development of the early Palaeogene deep-sea ecosystem.

Walvis Ridge ODP Site 1262 is located at $4759 \mathrm{~m}$ water depth near the base of Walvis Ridge (Angola Basin). Palaeocene sediments consist of nannofossil ooze with cyclic variations in sediment lightness and geochemistry, representing a response to orbital forcing (Westerhold et al., 2008). Palaeodepth was estimated as $\sim 3000-3300 \mathrm{~m}$, based on a simple thermal subsidence model and benthic foraminiferal assemblages (Shipboard Scientific Party, 2004a,b).

\section{Material and methods}

Stable isotope ratios $\left(\delta^{18} \mathrm{O}, \delta^{13} \mathrm{C}\right)$ for 91 samples from $9 \mathrm{~m}$ of core were measured on five Nuttallides truempyi specimens (size 125-180 $\mu \mathrm{m}$ ) per sample (Appendix S1). SEM images of broken N. truempyi (Appendix S2) reveal open pores, but also the presence of $\sim 1 \mu \mathrm{m}$ sized crystals of secondary calcite on interior walls. Since most recrystallization takes place in the upper sediment layers, benthic foraminifera preserve the stable isotope signature, even if recrystallized (Edgar et al., 2013; Voigt et al., 2016). Regression lines were calculated to investigate the relationship between the $\delta^{13} \mathrm{C}$ and the $\delta^{18} \mathrm{O}$ excursions. Major axis regression was used instead of ordinary least squares, because of measurement errors associated with both $\delta^{13} \mathrm{C}$ and $\delta^{18} \mathrm{O}$. Slopes were compared to those of major axis regression for early Eocene hyperthermals (data from Lauretano et al., 2015). Sedimentary $\mathrm{CaCO}_{3}$ was determined using a LECO device at the BGR in Hannover.

Benthic foraminiferal abundances were obtained from representative splits ( $>270$ specimens) of the $>63 \mu \mathrm{m}$ fraction. Benthic foraminifera were classified into epibenthic and endobenthic morphotypes according 
to Corliss and Chen (1988). Shannon diversity was calculated based on the data set with absolute counts (Hammer, 2015). Benthic foraminiferal accumulation rates (BFAR) were calculated by multiplying foraminiferal numbers per gram by sedimentation rate (option 2 age model of Westerhold et al., 2008) and Shipboard dry bulk densities (Shipboard Scientific Party, 2004b). Nonmetric multidimensional scaling (NMDS) on abundances for all taxa with a maximum relative abundance $>2 \%$ was run to identify the main patterns in the benthic foraminiferal abundances. The two-dimensional representation and the correlation distance measure were chosen (e.g. Hammer and Harper, 2006). To compare the LDE to early Eocene hyperthermals, $\Sigma_{\mathrm{CV}}$ were calculated following the biotic scaling approach of Gibbs et al. (2012). This measure associates one value with the overall assemblage variability in a certain time period. These were calculated on a data set with 3-point moving averages of all taxa with an average abundance of more than $1 \%$. More information on material and methods is available in Appendix S3.

\section{Results and discussion}

\section{Stable isotopes}

The isotopic record (Fig. 1) reveals two distinct negative peaks, which are apparent both in $\delta^{13} \mathrm{C}$ and $\delta^{18} \mathrm{O}$, at $\sim 62.1 \mathrm{Ma}(\sim 195 \mathrm{mcd})$, here termed LDE1 and LDE2. These two peaks coincide with higher $\mathrm{Fe}$, as revealed by XRF core scanning (Westerhold et al., 2008), and lower carbonate values (Fig. 4). LDE1 at Walvis Ridge starts at $62.18 \mathrm{Ma}(195.6 \mathrm{mcd})$, reaching lowest $\delta^{13} \mathrm{C}$ values at $62.14 \mathrm{Ma}$ (195.3 mcd). This CIE coincides with a $\sim 0.5 \%$ negative $\delta^{18} \mathrm{O}$ excursion, indicating $\quad 2.2{ }^{\circ} \mathrm{C} \quad$ bottom-water warming, assuming no local changes in $\delta^{18} \mathrm{O}_{\mathrm{SW}}$ due to salinity or ice volume. LDE2 peaks at $62.04 \mathrm{Ma}$ $(194.5 \mathrm{mcd})$ with a $\sim 0.5 \% \mathrm{CIE}$ and a $\sim 0.3 \% \delta^{18} \mathrm{O}$ excursion. Both isotopic records return to pre-LDE values in about $50 \mathrm{ka}$ at $61.99 \mathrm{Ma}$ (194.1 mcd).

These peaks correspond to those observed at Shatsky Rise sites 1209 and 1210, but Site 1262 shows a larger CIE $(0.9 \%$ compared to $0.6 \%$ o and warming $\left(2.2{ }^{\circ} \mathrm{C}\right.$ compared to

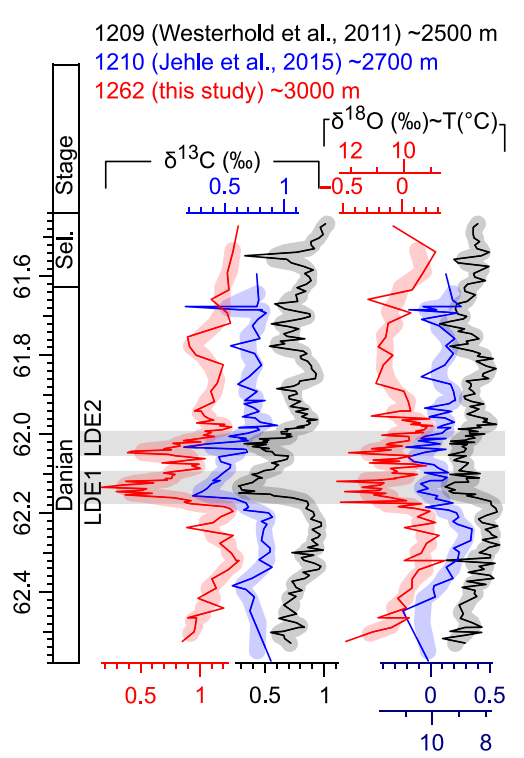

Fig. 1 Nuttallides truempyi isotope patterns at ODP Sites 1209, 1210 (Shatsky Rise, Pacific Ocean) and 1262 (Walvis Ridge, Atlantic Ocean) plotted against the numeric age model based on linear interpolation between the short-term eccentricity maxima of Westerhold et al. (2008), option 2. Thick lines represent a 3-point moving average. Records from Walvis Ridge and $\delta^{13} \mathrm{C}$ records were plotted on a different scale to prevent overlapping. Temperature estimates are according to the Erez and Luz (1983) palaeotemperature calculation with $1.2 \%$ ice-free standard mean ocean water (Shackleton and Kennett, 1975) and a $0.35 \%$ correction for Nuttallides vital effects (Shackleton et al., 1984). [Colour figure can be viewed at wileyonlinelibrary.com]

1.5-2 ${ }^{\circ} \mathrm{C}$ ) during LDE1. The LDE shows two CIEs, $100 \mathrm{ka}$ apart, a pattern it shares with ETM2-H2 and I1-I2 (Littler et al., 2014). All these CIEs are thought to relate to shortterm (100 ka) eccentricity maxima in one long-term (400 ka) eccentricity maximum (Westerhold et al., 2008; Hilgen et al., 2015). The slopes of major axis regression (Fig. 2) on the $\delta^{13} \mathrm{C}-\delta^{18} \mathrm{O}$ relationship for the LDE and early Eocene hyperthermals are plotted in Fig. 3. Compared to slopes for early Eocene hyperthermals, LDE1 has a similar slope to H1 (ETM2), J and K (ETM3). I1 has a slightly steeper slope than the other events, but is still within the $95 \%$ confidence intervals of all other events. LDE2 has a steeper slope then LDE1, but compared to the other secondary events in hyperthermal pairs, $\mathrm{H} 2$ and $\mathrm{I} 2$, it is in the lower range of the confidence interval. The relationship between the added mass of carbon divided by the initial mass of carbon in the oceanatmosphere system $\left(M_{\text {added }} / M_{\text {initial }}\right)$ and the $\delta^{13} \mathrm{C}$ change is given by $M_{\text {added }} / M_{\text {initial }}=-\mathrm{CIE} /\left(\delta^{13} \mathrm{C}_{\text {final }} \quad-\right.$ $\delta^{13} \mathrm{C}_{\text {added }}$ ) (McInerney and Wing, 2011). The slope of the relationship between $\delta^{13} \mathrm{C}$ and $\delta^{18} \mathrm{O}$ is dependent on climate sensitivity (temperature change per increase in $\left.\mathrm{CO}_{2}\right)$ and the $\delta^{13} \mathrm{C}$ value of the source of the reduced carbon. Climate sensitivity governs the relationship between $\delta^{18} \mathrm{O}$ (as a measure of temperature) and the amount of carbon added to the atmosphere $\left(M_{\text {added }} / M_{\text {initial }}\right)$. For more negative values of the carbon source, $\delta^{13} \mathrm{C}_{\text {final }}-\delta^{13} \mathrm{C}_{\text {added }}$ increases and the slope $\left(1 /\left(\delta^{13} \mathrm{C}_{\text {final - }}\right.\right.$ $\left.\left.\delta^{13} \mathrm{C}_{\text {added }}\right)\right)$ is less steep. Similar slopes thus point to similar climate sensitivities for Palaeocene and Eocene hyperthermals and a similar carbon source, although compensating effects of the two factors are also possible.

The difference in slope between the primary and secondary events was noted by Lauretano et al. (2015). Possible causes for this difference include a higher contribution of an isotopically less-negative source during the secondary events (because of incomplete filling of the carbon reservoir; Dickens, 2003), different climate feedbacks or local changes in circulation. The slope difference between the two LDE peaks could be caused by similar factors.

Four options can account for small changes in the slope of the $\delta^{13} \mathrm{C}-\delta^{18} \mathrm{O}$ regression for hyperthermals. The background $\delta^{13} \mathrm{C}$ values of the LDE are more positive because of long-term secular changes. These higher background values will cause a lower slope for the LDE, because the difference from the isotope signature of the source is larger. Then, the $\delta^{13} \mathrm{C}$ of the ocean-atmosphere system changes more rapidly for an equal $\mathrm{CO}_{2}$ rise. Alternatively, this slight change could reflect changes in climate sensitivity, as climate sensitivity seems to be higher at higher temperatures (Caballero and Huber, 2013; von der Heydt et al., 2014). The 

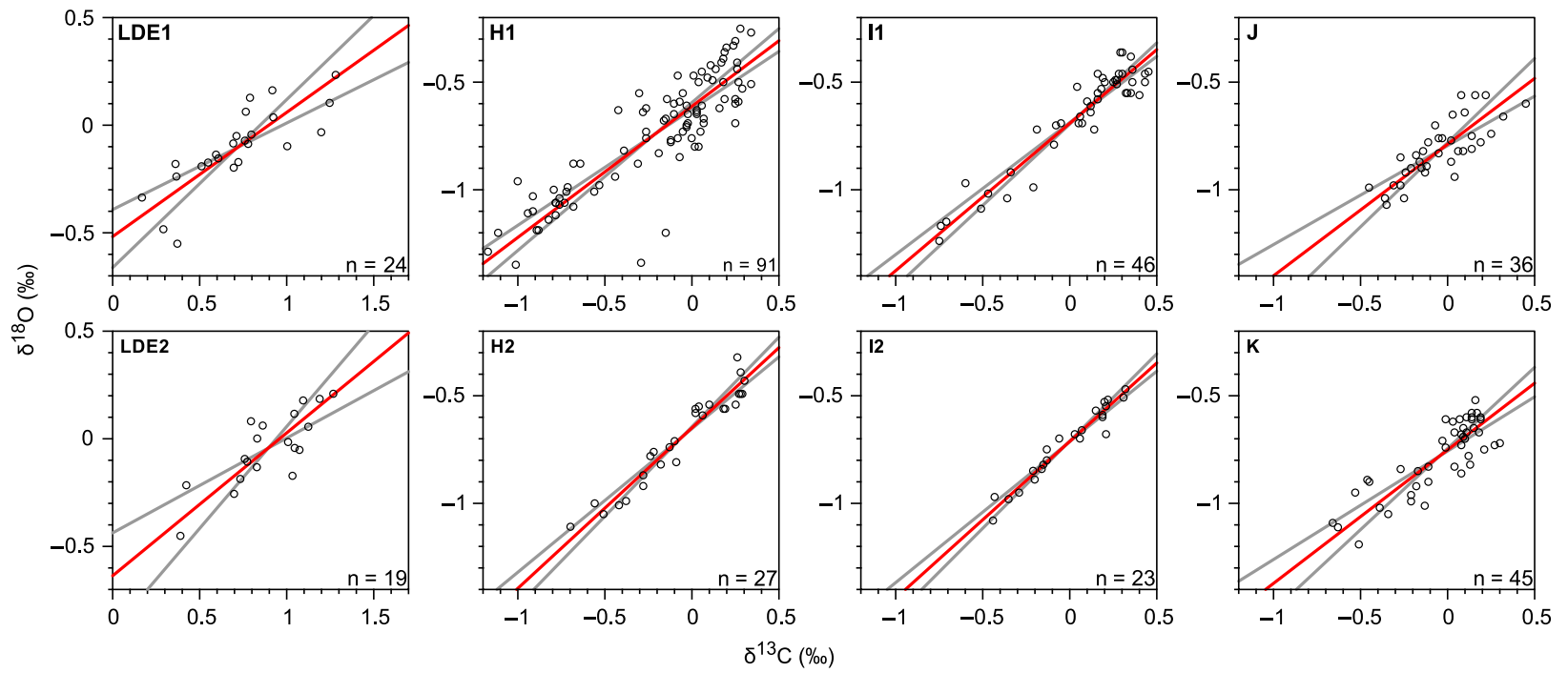

Fig. 2 Cross-plots for $\delta^{13} \mathrm{C}$ and $\delta^{18} \mathrm{O}$ for LDE1, LDE2, H1 (ETM2), H2, I1, I2, J and K (ETM3). All graphs show the regression line (major regression) in red and confidence intervals in grey. The major regression line shows similar relationships for $\delta^{13} \mathrm{C}$ and $\delta^{18} \mathrm{O}$ throughout the event for LDE1, H1, I1, J and K. Also, LDE2, H2 and I2 have similar $\delta^{13} \mathrm{C}-\delta^{18} \mathrm{O}$ slopes. Data for Eocene events are from Lauretano et al. (2015). The number of observations for each event is indicated in the lower right corner. [Colour figure can be viewed at wileyonlinelibrary.com]

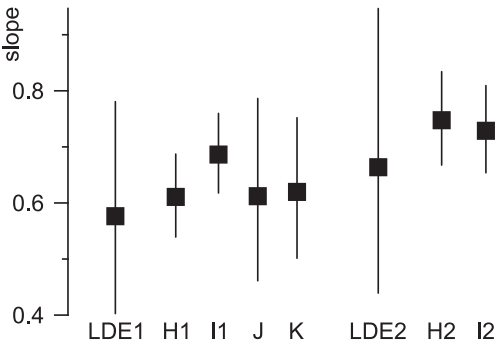

Fig. 3 Calculated slopes and 95\% confidence intervals of major axis regression for all studied hyperthermals. The numbers of observations for each event are indicated in Fig. 2. Second events of a hyperthermal pair are grouped on the right.

LDE is superimposed on a cooler climate than are the Eocene hyperthermals, and has a shallower slope (less $\delta^{18} \mathrm{O}$ change per unit change in $\left.\delta^{13} \mathrm{C}\right)$, as expected. A third option for differences in slope is a different isotope signature of the source. Relatively small differences in the isotope signature of the source can be caused by changes in atmospheric $\delta^{13} \mathrm{C}$, which is certainly the case if a reservoir is emptied during the hyperthermal and gradually filled afterwards (Dickens, 2003). As a last option, changes in climate and atmospheric $\mathrm{CO}_{2}$ concentration can cause changes in carbon fractionation of land plants (Diefendorf et al., 2010; Schubert and Jahren, 2012). The first and the third options can cancel each other out, as continuous fractionation between the atmosphere-ocean system and the carbon source is maintained by continuous refilling of the carbon source from ambient $\mathrm{CO}_{2}$. In this case, changing climate sensitivity would be responsible for the changing slope.

Similarities in isotopic composition of the carbon source and orbital configuration point to carbon input from a common reduced carbon reservoir causing both the LDE and the double-peaked early Eocene hyperthermals. The exact nature of this reduced carbon reservoir is still uncertain, but several release mechanisms have been proposed, such as the destabilization of gas hydrates due to deep-sea circulation changes, peat oxygenation by longer dry seasons or destabilization of permafrost during eccentricity maxima (Lunt et al., 2010; Zachos et al., 2010; DeConto et al., 2012).

\section{Benthic foraminifera}

Despite the marked benthic isotopic signature of the LDE and its similarity with the Eocene hyperthermals, especially ETM2-H2, the benthic foraminiferal record for the LDE at Site 1262 (Fig. 4) shows remarkable stability at the seafloor. The first, and most important, NMDS axis shows no faunal change at the base of the LDE. It separates a distinct biofacies just above the second LDE peak, coinciding with higher abundances of Paralabamina lunata. This species possibly feeds on a specific kind of fresh phytodetritus that is not consumed by other benthic foraminifera. Axis 2, which is less important, shows a small positive excursion during both LDE peaks, coinciding with somewhat higher abundances of $N$. truempyi (from $\sim 5 \%$ to $\sim 9 \%$ ) and other epibenthic morphotypes. Yet, as indicated by the low correlation with initial distances $\left(R^{2}=0.08\right)$, this axis hardly explains the main faunal patterns. On the other hand, a higher abundance of $N$. truempyi and epibenthic morphotypes generally points to more oligotrophic conditions (Thomas, 1998), consistent with lower BFAR (from $\sim 500$ to $\sim 400 \mathrm{~cm}^{-2} \mathrm{ka}^{-1}$ ) during most of the LDE.

An increasing relative abundance of $N$. truempyi and epifaunal morphotypes is also reported at Walvis Ridge during the PETM (Thomas, 2007), ETM2 (Jennions et al., 2015) 


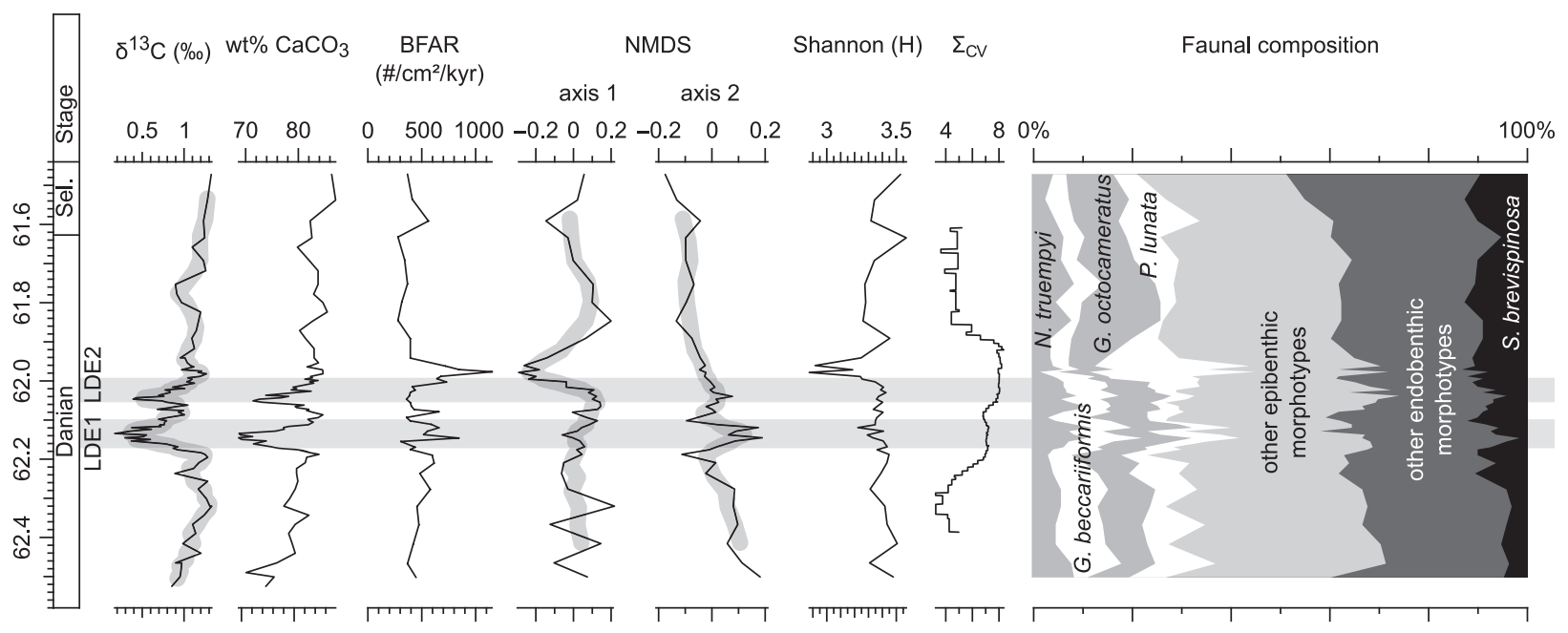

Fig. $4 \delta^{13} \mathrm{C}$ patterns, weight percentage of carbonate in bulk samples, benthic foraminiferal accumulation rates (numbers per $\mathrm{cm}^{2}$ per ka), first and second NMDS axes of benthic foraminiferal relative abundances, Shannon diversity, $\Sigma_{\mathrm{CV}}$ calculated for a sliding time window of $150 \mathrm{kyr}$ symmetric about the data point, and relative abundances of epi- and endobenthic morphotypes and the five most abundant benthic foraminifera: N. truempyi, Gavelinella beccariiformis, Gyroidinoides octocameratus, P. lunata and Siphogenerinoides brevispinosa. All faunal data are reported in Appendix S1.

and ETM3 (Röhl et al., 2006), in addition to higher numbers of abyssaminids during the Eocene events. However, increases in the relative abundance of N. truempyi and Abyssamina poagi $(+10 \%)$ and decreases in BFAR (from $\sim 200$ to $\sim 10 \mathrm{~cm}^{-2} \mathrm{ka}^{-1}$ ) and diversity (from $\sim 35$ to $\sim 25$ species per 100 counts; Jennions et al., 2015) were much larger during ETM2. The increased abundance of thin-shelled A. poagi indicates that dissolution did not cause these decreases during ETM2. Comparing $\Sigma_{\mathrm{CV}}$ values, the difference between the events becomes even clearer. The $\Sigma_{\mathrm{CV}}$ of the background Palaeocene (pre-LDE) is $\sim 5$ (Fig. 4). The $\Sigma_{\mathrm{CV}}$ of $\sim 7$ for LDE1 is only slightly larger. The $\Sigma_{\mathrm{CV}}$ for ETM2 (data of Jennions et al., 2015) reaches 13. No Eocene background could be assessed, because Jennions et al. (2015) only studied the ETM2 event. Overall, the LDE at Walvis Ridge shows comparable faunal changes, but with a much reduced intensity. These minor assemblage changes, however, contrast with CIEs $(\sim 0.9 \%$ for LDE, $\sim 1.4 \%$ for ETM2, $\sim 0.8 \%$ for ETM3; Table 1) and temperature changes $\left(2{ }^{\circ} \mathrm{C}\right.$ for LDE1 and ETM3, $4{ }^{\circ} \mathrm{C}$ for ETM2; Table 1) of nearly identical magnitude.

Short-term deep-sea circulation changes in the Atlantic Ocean were inferred during ETM2 (D'haenens et al., 2014; Jennions et al., 2015) and the PETM (McCarren et al., 2008) in order to explain impoverished benthic foraminiferal assemblages due to oligotrophy (D'haenens et al., 2012) and/ or lower dissolved $\mathrm{O}_{2}$ (McCarren et al., 2008; Jennions et al., 2015). D'haenens et al. (2014) suggested that this circulation change was threshold based, and these circulation changes were not observed in connection with CIEs slightly smaller than ETM2. The CIE and temperature rise of the LDE are indeed slightly smaller than at ETM2 and ETM3 (Table 1), but the absolute bottom-water temperatures during ETM2 $\left(\sim 14^{\circ} \mathrm{C}\right)$ and ETM3 $\left(\sim 15^{\circ} \mathrm{C}\right)$ were significantly higher than those during the LDE $\left(\sim 11{ }^{\circ} \mathrm{C}\right)$. The possibility of crossing an absolute temperature threshold is thus higher.

Table 1 Overview of data for the hyperthermals. The table includes the slopes (Fig. 3), $\delta^{18} \mathrm{O}$ values pre-event and $300 \mathrm{ka}$ before the event, peak values and excursion sizes, $\delta^{13} \mathrm{C}$ pre-event, peak values and excursion sizes and temperature trends prior to the event, peak values and excursion sizes. Isotope records for Eocene events are from Lauretano et al. (2015).

\begin{tabular}{|c|c|c|c|c|c|c|c|c|c|c|c|}
\hline \multirow[b]{2}{*}{ Event } & \multirow[b]{2}{*}{ Slope } & \multirow{2}{*}{$\begin{array}{l}300 \text { ka prior } \\
\text { to event } \\
\delta^{18} 0\end{array}$} & \multirow{2}{*}{$\begin{array}{l}\text { Pre-event } \\
\delta^{18} 0\end{array}$} & \multirow{2}{*}{$\begin{array}{l}\text { Trend } \\
\mathrm{T}\left({ }^{\circ} \mathrm{C}\right)\end{array}$} & \multirow{2}{*}{$\begin{array}{l}\text { Pre-event } \\
\delta^{13} \mathrm{C}\end{array}$} & \multicolumn{3}{|c|}{ Peak values } & \multicolumn{3}{|c|}{ Excursion } \\
\hline & & & & & & $\delta^{18} 0$ & $\mathrm{~T}\left({ }^{\circ} \mathrm{C}\right)$ & $\delta^{13} \mathrm{C}$ & $\delta^{18} 0$ & $\mathrm{~T}\left({ }^{\circ} \mathrm{C}\right)$ & $\delta^{13} \mathrm{C}$ \\
\hline LDE1 & 0.576 & -0.1 & 0.2 & -1.3 & 1.3 & -0.3 & 11.4 & 0.4 & 0.5 & 2.2 & 0.9 \\
\hline H1 (ETM2) & 0.611 & -0.3 & -0.2 & 0.2 & 0.3 & -1 & 14.5 & -1 & 0.8 & 3.6 & 1.3 \\
\hline I1 & 0.686 & -0.4 & -0.5 & 0.4 & 0.4 & -1.2 & 15.4 & -0.6 & 0.7 & 3.1 & 1 \\
\hline J & 0.612 & -0.5 & -0.6 & 0.4 & 0.3 & -0.9 & 14.1 & -0.2 & 0.3 & 1.3 & 0.5 \\
\hline K (ETM3) & 0.620 & -0.5 & -0.6 & 0.4 & 0.2 & -1.1 & 15.0 & -0.6 & 0.5 & 2.2 & 0.8 \\
\hline LDE2 & 0.664 & & 0 & & 0.9 & -0.3 & 11.4 & 0.4 & 0.3 & 1.3 & 0.5 \\
\hline $\mathrm{H} 2$ & 0.748 & & -0.4 & & 0.2 & -1 & 14.5 & -0.6 & 0.6 & 2.7 & 0.8 \\
\hline 12 & 0.729 & & -0.5 & & 0.4 & -1 & 14.5 & -0.3 & 0.5 & 2.2 & 0.7 \\
\hline
\end{tabular}


$\delta^{18} \mathrm{O}$ data from Shatsky Rise indicate a deep-water long-term cooling trend from $63.0 \mathrm{Ma}\left(\sim 10^{\circ} \mathrm{C}\right)$ to $58.5 \mathrm{Ma}\left(\sim 7^{\circ} \mathrm{C}\right)$, briefly interrupted during the LDE (Westerhold et al., 2011). The LDE is the only early Palaeogene hyperthermal superimposed on such a cooling trend for which the benthic foraminiferal fauna has been studied (Table 1). During the LDE, deep-sea temperatures were similar to those prevailing some 0.4-1 Ma earlier (Westerhold et al., 2011 and Fig. 1). Under gradually changing conditions, benthic foraminiferal genetic evolution will lag behind environmental change (Lynch and Lande, 1993) because benthic foraminifera evolve slowly (Pawlowski et al., 2007) but can adapt by phenotypic plasticity (Chevin et al., 2010). In a gradually cooling deep sea, this lag in genetic adaptation would lead to species well-adapted to higher temperatures than the prevailing conditions. Accordingly, a brief interruption of long-term cooling during the LDE would not affect deep-sea communities, as shown by our data.

\section{Conclusions}

The early Palaeocene LDE hyperthermal event bears some striking similarities in environmental and biotic characterization to the PETM. Furthermore, both the LDE and early Eocene hyperthermals ETM2H2 and I1-I2 at Site 1262, Walvis Ridge, show orbitally paced doublepeaked $\delta^{13} \mathrm{C}$ and $\delta^{18} \mathrm{O}$ excursions with a similar relationship between $\delta^{13} \mathrm{C}$ and $\delta^{18} \mathrm{O}$ changes, strongly suggesting a shared astronomically controlled causal mechanism. Yet, in contrast to ETM2-H2 (and the PETM), benthic foraminiferal faunal patterns show remarkable stability at the seafloor during the LDE. This discrepancy may be explained by the rather cool early Palaeocene background deep-sea temperature and the lack of threshold-related circulation changes, in contrast to the early Eocene hyperthermals. In addition, benthic communities were welladapted to higher temperatures, as the LDE was superimposed on an early Palaeocene cooling trend, in contrast to the warming trend during the early Eocene hyperthermals.

\section{Acknowledgements}

This manuscript benefitted from comments by Appy Sluijs and two anonymous reviewers on a previous version of the manuscript and comments by the editor on this manuscript. This research used samples and data provided by the ODP. Financial support was provided by the KU Leuven Research Fund to RPS and the DFG to AB (BO2505/8-1, EH 89/20). G. Grützner (BGR) is thanked for preparing samples for LECO analyses.

\section{References}

Bornemann, A., Schulte, P., Sprong, J., Steurbaut, E., Youssef, M. and Speijer, R.P., 2009. Latest Danian carbon isotope anomaly and associated environmental change in the southern Tethys (Nile Basin, Egypt). J. Geol. Soc., 166, 1135-1142.

Caballero, R. and Huber, M., 2013. State-dependent climate sensitivity in past warm climates and its implications for future climate projections. Proc. Natl Acad. Sci., 110, 14162-14167.

Chevin, L.-M., Lande, R. and Mace, G.M., 2010. Adaptation, plasticity, and extinction in a changing environment: towards a predictive theory. PLoS Biol., 8, e1000357.

Clyde, W.C., Tong, Y., Snell, K.E., Bowen, G.J., Ting, S., Koch, P.L., Li, Q., Wang, Y. and Meng, J., 2008. An integrated stratigraphic record from the Paleocene of the Chijiang Basin, Jiangxi Province (China): implications for mammalian turnover and Asian block rotations. Earth Planet. Sci. Lett., 269, 554-564.

Corliss, B.H. and Chen, C., 1988. Morphotype patterns of Norwegian Sea deep-sea benthic foraminifera and ecological implications. Geology, 16, 716-719.

DeConto, R.M., Galeotti, S., Pagani, M., Tracy, D., Schaefer, K., Zhang, T., Pollard, D. and Beerling, D.J., 2012. Past extreme warming events linked to massive carbon release from thawing permafrost. Nature, 484, 87-91.

D'haenens, S., Bornemann, A., Stassen, P. and Speijer, R.P., 2012. Multiple early Eocene benthic foraminiferal assemblage and $\delta^{13} \mathrm{C}$ fluctuations at DSDP Site 401 (Bay of Biscay - NE Atlantic). Mar. Micropaleontol., 88-89, $15-35$.

D'haenens, S., Bornemann, A., Claeys, P., Röhl, U., Steurbaut, E. and Speijer, R.P., 2014. A transient deep-sea circulation switch during Eocene Thermal Maximum 2.

Paleoceanography, 29, 370-388.

Dickens, G.R., 2003. Rethinking the global carbon cycle with a large, dynamic and microbially mediated gas hydrate capacitor. Earth Planet. Sci. Lett., 213, 169-183.

Diefendorf, A.F., Mueller, K.E., Wing, S.L., Koch, P.L. and Freeman, K.H., 2010. Global patterns in leaf ${ }^{13} \mathrm{C}$ discrimination and implications for studies of past and future climate. Proc. Natl Acad. Sci., 107, 5738-5743.

Edgar, K.M., Pälike, H. and Wilson, P.A., 2013. Testing the impact of diagenesis on the $\delta^{18} \mathrm{O}$ and $\delta^{13} \mathrm{C}$ of benthic foraminiferal calcite from a sediment burial depth transect in the equatorial Pacific. Paleoceanography, 28, 468-480.

Erez, J. and Luz, B., 1983. Experimental paleotemperature equation for planktonic foraminifera. Geochim. Cosmochim. Acta, 47, 1025-1031.

Gibbs, S.J., Bown, P.R., Murphy, B.H., Sluijs, A., Edgar, K.M., Pälike, H., Bolton, C.T. and Zachos, J.C., 2012. Scaled biotic disruption during early Eocene global warming events. Biogeosci., 9, 4679-4688.

Hammer, Ø., 2015. PAST reference manual, version 3.08 (folk.uio.no/oha mmer/past/past3manual.pdf), 243 pp.

Hammer, Ø. and Harper, D.A.T., 2006. Paleontological Data Analysis. Blackwell Publishing, Oxford, UK. von der Heydt, A.S., Köhler, P., van de Wal, R.S.W. and Dijkstra, H.A., 2014. On the state dependency of fast feedback processes in (paleo) climate sensitivity. Geophys. Res. Lett., 41, 6484-6492.

Hilgen, F.J., Abels, H.A., Kuiper, K.F., Lourens, L.J. and Wolthers, M., 2015. Towards a stable astronomical time scale for the Paleocene: aligning Shatsky Rise with the Zumaia - Walvis Ridge ODP Site 1262 composite. Newsl. Stratigr., 48, 91-110.

Jehle, S., Bornemann, A., Deprez, A. and Speijer, R.P., 2015. The impact of the Latest Danian Event on planktic foraminiferal faunas at ODP Site 1210 (Shatsky Rise, Pacific Ocean). PLoS ONE, 10, e0141644.

Jennions, S.M., Thomas, E., Schmidt, D.N., Lunt, D. and Ridgwell, A., 2015. Changes in benthic ecosystems and ocean circulation in the Southeast Atlantic across Eocene Thermal Maximum 2. Paleoceanography, $\mathbf{3 0}$, 1059-1077.

Lauretano, V., Littler, K., Polling, M., Zachos, J.C. and Lourens, L.J., 2015. Frequency, magnitude and character of hyperthermal events at the onset of the Early Eocene Climatic Optimum. Clim. Past, 11, 1313-1324.

Littler, K., Röhl, U., Westerhold, T. and Zachos, J.C., 2014. A high-resolution benthic stable-isotope record for the South Atlantic: implications for orbital- 
scale changes in Late Paleocene-Early Eocene climate and carbon cycling. Earth Planet. Sci. Lett., 401, 18-30.

Lunt, D.J., Valdes, P.J., Jones, T.D., Ridgwell, A., Haywood, A.M. Schmidt, D.N., Marsh, R. and Maslin, M., 2010. $\mathrm{CO}_{2}$-driven ocean circulation changes as an amplifier of PaleoceneEocene Thermal Maximum hydrate destabilization. Geology, 38, 875-878.

Lynch, M. and Lande, R., 1993.

Evolution and extinction in response to environmental change. In: Biotic Interactions and Global Change (P. Kareiva, J. Kingsolver and R. Huey, eds.), pp. 234-250. Sinauer Associates, Sunderland, Massachusetts.

McCarren, H., Thomas, E., Hasegawa, T., Röhl, U. and Zachos, J.C., 2008. Depth dependency of the PaleoceneEocene carbon isotope excursion: paired benthic and terrestrial biomarker records (Ocean Drilling Program Leg 208, Walvis Ridge). Geochem. Geophys. Geosyst., 9, Q10008.

McInerney, F.A. and Wing, S.L., 2011. The Paleocene-Eocene Thermal Maximum: a perturbation of carbon cycle, climate, and biosphere with implications for the future. Anпu. Rev. Earth Planet. Sci., 39, 489-516.

Monechi, S., Reale, V., Bernaola, G. and Balestra, B., 2013. The Danian/ Selandian boundary at Site 1262 (South Atlantic) and in the Tethyan region: biomagnetostratigraphy, evolutionary trends in fasciculiths and environmental effects of the Latest Danian Event. Mar. Micropaleontol., 98, 28-40.

Pawlowski, J., Fahrni, J., Lecroq, B., Longet, D., Cornelius, N., Excoffier, L., Cedhagen, T. and Gooday, A.J., 2007. Bipolar gene flow in deep-sea benthic foraminifera. Mol. Ecol., 16, 4089-4096.

Röhl, U., Westerhold, T., Monechi, S., Thomas, E., Zachos, J.C. and Donner, B., 2006. The third early Eocene thermal maximum: characteristics, timing, and mechanisms of the " $\mathrm{X}$ " Event. Geophys. Res. Abstr., 8, 04560.

Schubert, B.A. and Jahren, A.H., 2012. The effect of atmospheric $\mathrm{CO}_{2}$ concentration on carbon isotope fractionation in $\mathrm{C}_{3}$ land plants. Geochim. Cosmochim. Acta, 96, 29-43.

Schulte, P., Schwark, L., Stassen, P., Kouwenhoven, T.J., Bornemann, A. and Speijer, R.P., 2013. Black shale formation during the Latest Danian Event and the Paleocene-Eocene Thermal Maximum in central Egypt: two of a kind? Palaeogeogr.

Palaeoclimatol. Palaeoecol., 371, 9-25.

Shackleton, N.J. and Kennett, J.P., 1975. Paleotemperature history of the Cenozoic and the initiation of Antarctic glaciation: oxygen and carbon isotope analyses in DSDP sites 277, 279, and 281. Init. Rep. Deep Sea Drilling Proj., 29, 743-755.

Shackleton, N.J., Hall, M.A. and Boersma, A., 1984. Oxygen and carbon isotope data from Leg 74 foraminifers. In: Initial Reports of the Deep Sea Drilling Project, Vol. 74 (T.C. Moore Jr., P.D. Rabinowitz, A. Boersma, P.E. Borella, A.D. Chave, G. Duée, D.K. Fütterer, M.-J. Jiang, K. Kleinert, A. Lever, H. Manivit, S. O'Connell, S.H. Richardson, N.J. Shackleton, J.H. Blakeslee and M. Lee, eds.), pp. 599 612. Texas A\&M University, Ocean Drilling Program, College Station, Texas.

Shipboard Scientific Party, 2004a. Leg 208 summary. In: Proceedings of the Ocean Drilling Program, Initial Reports, Vol. 208 (J.C. Zachos, D. Kroon, P. Blum, J. Bowles, P. Gaillot, T. Hasegawa, E.C. Hathorne, D.A. Hodell, D.C. Kelly, J.-H. Jung, S.M. Keller, Y.S. Lee, D.C. Leuschner, L. Zhifei, K.C. Lohmann, L. Lourens, S. Monechi, M.J. Nicolo, I. Raffi, C. Riesselman, U. Röhl, S.A. Schellenberg, D. Schmidt, A. Sluijs, D.J. Thomas, E. Thomas, H. Vallius, H. Neville and K. Sherar, eds.), pp. 1112. Texas A\&M University, Ocean Drilling Program, College Station, Texas.

Shipboard Scientific Party, 2004b. Site 1262. In: Proceedings of the Ocean Drilling Program, Initial Reports, Vol. 208 (J.C. Zachos, D. Kroon, P. Blum, J. Bowles, P. Gaillot, T. Hasegawa, E.C. Hathorne, D.A. Hodell, D.C. Kelly, J.-H. Jung, S.M. Keller, Y.S. Lee, D.C. Leuschner, L. Zhifei, K.C. Lohmann, L. Lourens, S. Monechi, M.J. Nicolo, I. Raffi, C. Riesselman, U. Röhl, S.A. Schellenberg,

D. Schmidt, A. Sluijs, D.J. Thomas, E. Thomas, H. Vallius, H. Neville and K. Sherar, eds.), pp. 1-92. Texas A\&M University, Ocean Drilling Program, College Station, Texas.

Sprong, J., Kouwenhoven, T.J., Bornemann, A., Schulte, P., Stassen, P., Steurbaut, E., Youssef, M. and Speijer, R.P., 2012. Characterization of the Latest Danian Event by means of benthic foraminiferal assemblages along a depth transect at the southern Tethyan margin (Nile Basin, Egypt). Mar. Micropaleontol., 86-87, 15-31.

Stap, L., Lourens, L.J., Thomas, E., Sluijs, A., Bohaty, S. and Zachos, J.C., 2010. High-resolution deep-sea carbon and oxygen isotope records of Eocene Thermal Maximum 2 and H2. Geology, 38, 607-610.
Thomas, E., 1998. Biogeography of the late Paleocene benthic foraminiferal extinction. In: Late Paleocene - Early Eocene Climatic and Biotic Events in the Marine and Terrestrial Records (M.-P. Aubry, S.G. Lucas and W.A. Berggren, eds), pp. 214-243. Columbia University Press, New York, NY.

Thomas, E., 2007. Cenozoic mass extinctions in the deep sea: what perturbs the largest habitat on Earth? In: Large Ecosystem Perturbations: Causes and Consequences (S. Monechi, R. Coccioni and M. Rampino, eds.). Geol. Soc. Am. Spec. Pap., 424, 1-23.

Voigt, J., Hathorne, E.C., Frank, M. and Holbourn, A., 2016. Minimal influence of recrystallization on middle Miocene benthic foraminiferal stable isotope stratigraphy in the eastern equatorial Pacific. Paleoceanography, 31, 98-114.

Westerhold, T., Röhl, U., Raffi, I., Fornaciari, E., Monechi, S., Reale, V., Bowles, J. and Evans, H.F., 2008. Astronomical calibration of the Paleocene time. Palaeogeogr. Palaeoclimatol. Palaeoecol., 257, 377403.

Westerhold, T., Röhl, U., Donner, B., McCarren, H.K. and Zachos, J.C., 2011. A complete high-resolution Paleocene benthic stable isotope record for the central Pacific (ODP Site 1209). Paleoceanography, 26, PA2216.

Zachos, J.C., McCarren, H., Murphy, B., Röhl, U. and Westerhold, T., 2010. Tempo and scale of late Paleocene and early Eocene carbon isotope cycles: implications for the origin of hyperthermals. Earth Planet. Sci. Lett., 299, 242-249.

Received 11 October 2016; revised version accepted 23 November 2016

\section{Supporting Information}

Additional Supporting Information may be found in the online version of this article:

Appendix S1. Data files: wt $\%$ $\mathrm{CaCO}_{3}$, calculation of accumulation rates of planktic and benthic foraminifera, Shannon diversity, NMDS scores, relative abundances of epi- and endobenthic taxa and the most abundant taxa, isotope measurements.

Appendix S2. SEM micrographs of uncleaned Nuttallides truempyi.

Appendix S3. More extensive method treatment. 